\title{
Gene Deletion and Duplication Effects on Phenotype and Gamma Globulin Levels
}

\author{
NOREEN L. RUDD and PAUL H. LAMARCHE
}

\begin{abstract}
From the Division of Medical Genetics, Department of Pathology and Pediatrics, Child Development and Birth Defects Center, Rhode Island Hospital, Providence, Rhode Island, U.S.A.
\end{abstract}

In 1964, de Grouchy described the clinical picture associated with partial monosomy for No. 18 chromosome due to a deletion of part of the long arms (de Grouchy et al., 1964a, b). Subsequent case reports have confirmed a phenotypic similarity in individuals with this deletion.

Edwards and associates (1960) described a new autosomal trisomy, that of chromosome 18. Since their report, there have been many similar cases described. However, there have also been several cases reported of partial trisomy for No. 18 chromosome due to translocation of part of this chromosome on to another autosome.

We are reporting a family in which there is both a monosomic and a trisomic condition for a portion of the long arms of No. 18 chromosome transmitted through three generations by balanced carriers.

\section{Clinical Findings}

Case III.1 (date of birth 30 April 1968). The proband of this family (Fig. 1) is a male infant who was admitted to Rhode Island Hospital at 2 months of age for investigation of failure to thrive. He was the product of a full-term pregnancy of a Gravida 1 Para 0 unmarried female who had taken two types of unknown abortifacients during the 6th to 9th week of gestation. Paternal identity was withheld. The infant was born by spontaneous breech delivery, weighing $3570 \mathrm{~g}$. with a good Apgar rating at 5 minutes.

On examination he was found to be a pale, scrawny, irritable infant with mild dehydration and poor subcutaneous fat. His weight was $3884 \mathrm{~g}$., height $58 \mathrm{~cm}$., and head circumference $38.5 \mathrm{~cm}$. His head was scaphycephalic; he had a flattened nasal bridge with small nose, epicanthic folds, brushfield spots, thin lips with downturned corners of the mouth, and a high arched palate. The ears were low set, soft, small, and flat, with minimal hypertrophy of the antitragus and absence of the bifurcation of the antihelix. There was mild retraction of the mid-face. His neck was short;

Received 20 April 1970.

7-J.M.G. the nipples were widely spaced. Examination of the extremities revealed fusiform fingers, clinodactyly of the fifth digit, a proximal take-off of the thumbs, forefoot adduction of the left foot, mild bilateral pes cavus, and a wide space between the first and second toes. He had a protuberant soft abdomen and a low pitch hoarse cry. He was mildly hypotonic. There was a grade I/VI soft systolic murmur at the pulmonary area. He was unable to follow an object with his eyes; he could not raise his head off the bed in a prone position.

During his hospital stay he was noted to be a slow feeder and frequently regurgitated small amounts of his feeding. Stools were normal. Irregular respiratory rhythm was noted with apnoea for up to 10 seconds during sleep.

Initial laboratory studies revealed a normal intravenous pyelogram, skull $x$-ray, upper gastrointestinal series, and chest $x$-ray. Lumbar puncture, serum electrolytes, stool culture, and electroencephalogram were normal. Haemoglobin was $11.5 \mathrm{~g} . / 100 \mathrm{ml}$. Blood was drawn for chromosomal analysis and he was discharged with the diagnosis of acute gastroenteritis.

The child was readmitted to hospital at 4 months of age with a 2-month history of failure to thrive associated with diarrhoea and projectile vomiting. He had been on Similac, farina, strained solid foods, Vi-Penta, ${ }^{*}$ Ilosone $\dagger$ $50 \mathrm{mg}$. three times a day, ascorbic acid twice a day, and a trial of Bentyl with phenobarbital $\ddagger$ without effect.

Examination revealed a hypotonic, emaciated moderately dehydrated infant with generalized redundant skin, hyporeflexia, and protruding tongue, in addition to the features mentioned above. His developmental age was $\frac{1}{2}$ to $\frac{1}{3}$ his chronological age.

Laboratory studies revealed the following: upper gastrointestinal series showed flocculation of opaque media, consistent with malabsorption; bone age normal; blood urea nitrogen $14 \mathrm{mg}$. $/ 100 \mathrm{ml}$. ; calcium $4.9 \mathrm{mEq} / 1$.; phosphorus $4.9 \mathrm{mEq} / \mathrm{l}$; ; electrolytes normal; fasting blood sugar $77 \mathrm{mg} . / 100 \mathrm{ml}$; s serum thyroxin $4.0 \mu \mathrm{g}$./ $100 \mathrm{ml}$; ; prothrombin $83 \%$; carotene $3 \mu \mathrm{g} . / 100 \mathrm{ml}$;

* Vi-Penta Infant Drops (Roche Laboratories, Nutley, New Jersey).

t Ilosone (Eli Lilly and Company, 740 S. Alabama St., Idianapolis, Indiana).

$¥$ Bentyl (The Wm. S. Merrell Company, Cincinnati, Ohio). 


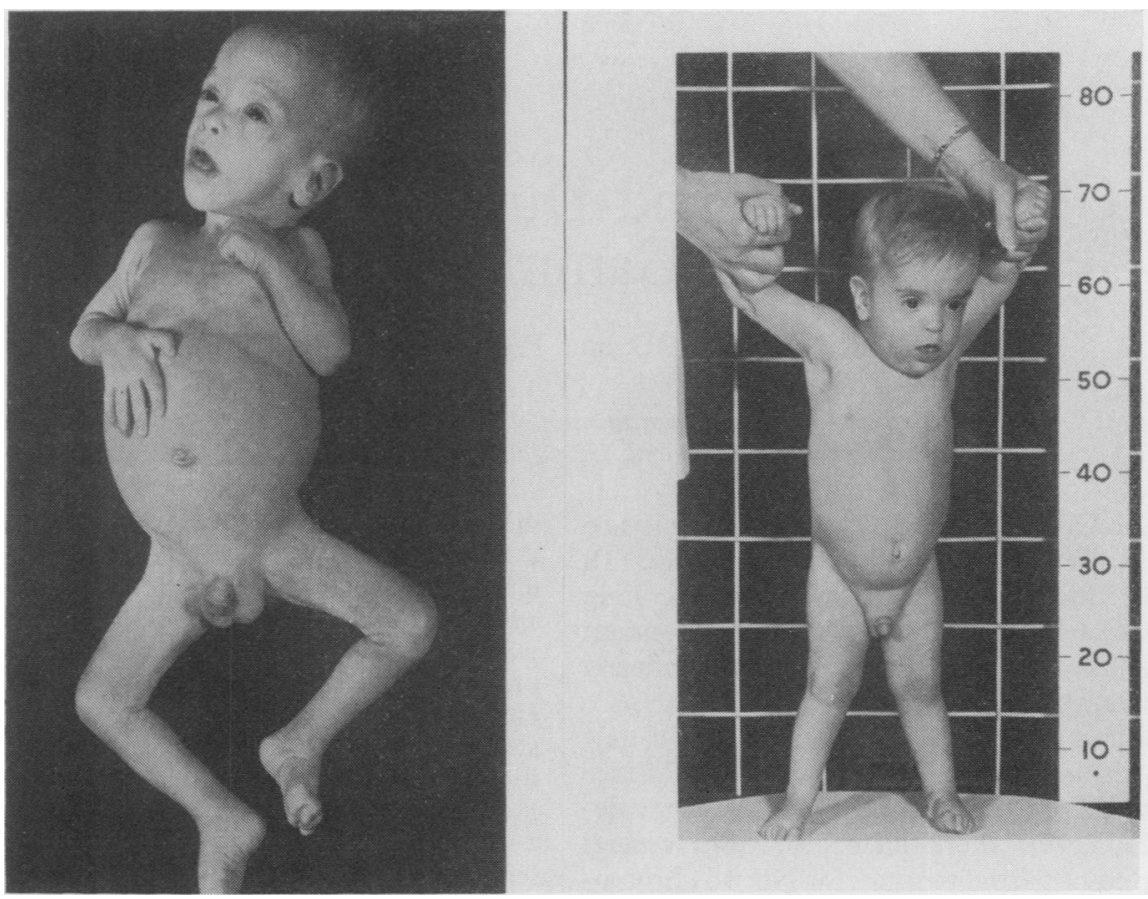

Fig. 1. The proband, Case III.1. (a) Age 4 months; (b) age 13 months.

milk antibodies weakly positive, becoming negative by 1 year of age; urinalysis normal; 24-hour urine amino acid chromatogram showed normal pattern; D-xylose abnormal, consistent with malabsorption; vanillyl mandelic acid $490 \mu \mathrm{g} . / 24$ hours; cerebral spinal fluid normal; sodium by iontophoresis $37 \mathrm{mEq} / 1$; anti $A 1: 4$; anti $B$ 1:8; typhoid $\mathrm{H}$ antibody titre rose from 0 to $1: 320$ in one month after immunization; jejunal biopsy normal; stool for reducing substance negative; stool $\mathrm{pH}$ 6; stool culture grew pathogenic Esch. coli 0125 on one occasion; 72-hour stool fat was $14.6 \mathrm{~g}$./24 hours.

The child was placed on Portagen* and Viokaset without beneficial effect. A trial of tetracycline and neomycin was given with transient decrease in the steatorrhea. At age 9 months he was started on the Schwarz $\ddagger 62 \mathrm{H}$ elemental diet which is a laboratory prepared high protein diet. His weight immediately began to increase and the steatorrhoea disappeared. He was discharged to a foster home on the Schwarz diet at 13 months of age, weighing $7568 \mathrm{~g}$.

Case II.9 (date of birth 29 July 1949). This 19year-old girl is the mother of the proband of this pedigree. Physical examination: height $170 \mathrm{~cm}$., weight $61 \mathrm{~kg}$., a single palmar crease on her right hand. The

* Portagen (Mead Johnson Laboratories, 2404 W. Pennsylvania St. Evansville, Indiana).

+ Viokase (VioBin Corporation, Montocello, Illinois).

₹ Schwarz diet supplied by Schwarz BioResearch Lab., Orangeburg, New York). remainder of the examination was within normal limits, $\mathbb{D}$ with the exception of an alternating exotropia. She is of dull normal to borderline retarded intelligence.

Case II.8 (date of birth 8 February 1946) (Fig. 2a). This 22-year-old man is an uncle of the proband. He was the product of a full-term pregnancy of a 36-yearold mother and father, weighing $2663 \mathrm{~g}$. The child apparently crawled at age 3 years, walked at age 4 years, and never talked. His past medical history included operation for a pilonidal cyst, a right inguinal herniorr- $\delta$ haphy, and a right orchiopexy. At age 8 years, he was admitted permanently to the Ladd School, a residential $O$ school for the mentally retarded.

Examination revealed a short slight male; height $\frac{7}{6}$ $156 \mathrm{~cm}$.; weight $40.8 \mathrm{~kg}$; head circumference $54 \mathrm{~cm}$. 三 He was normocephalic, with slight hypertelorism, low $\mathcal{N}$ hairline, high arched palate, and hypoplasia of the dental $N$ enamel. His sternum was hypoplastic and deformed. Examination of the extremities revealed bilateral simian $\omega$ creases, long fingers, mild clinodactyly of the index and $\underset{\gamma}{\sigma}$ fifth fingers, and pes cavus. He had a small right testicle 0 and non-palpable left testicle. All secondary sex $\stackrel{\complement}{\mathscr{D}}$ characteristics were present. He had a generalized hypertonia giving his gait a 'robot' appearance. Though no speech was present, he could comprehend and follow simple commands.

Case II.7 (date of birth 27 March 1944) (Fig. 2b). This 24-year-old man is also an uncle of the proband. 
He was the product of a full-term pregnancy weighing $3203 \mathrm{~g}$. He had very delayed motor milestones. At the age of 10 years, he was admitted to the Ladd School for long-term care. At the age of 11 years, he had developmental age of 6 to 12 months on the Gesell and at the age of 15 years his IQ was less than 30 on the WISC. His past

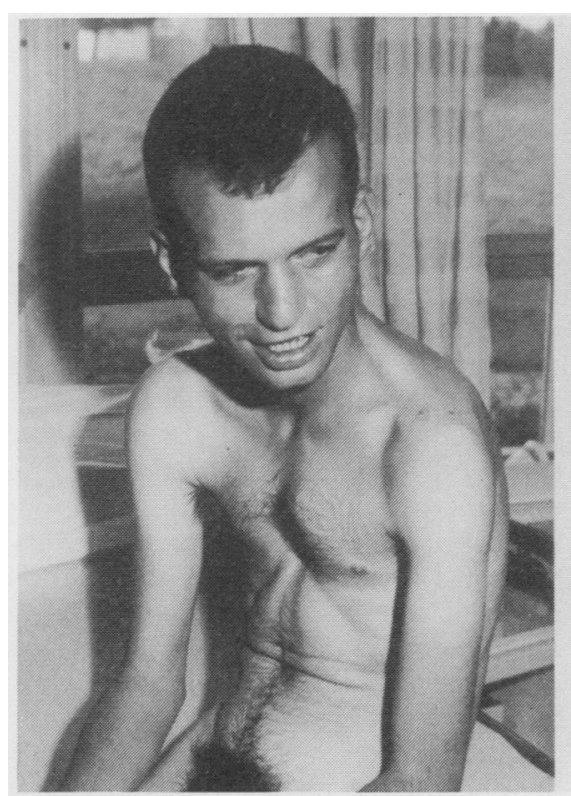

(a)

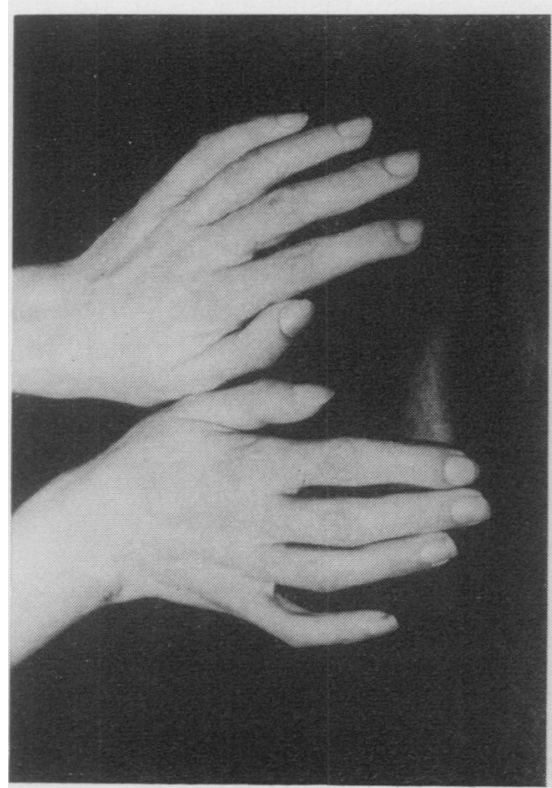

(c) medical history reveals that he had a bilateral inguinal hernia repair. Intravenous pyelogram showed mildly dilated renal pelvis and calyces due to an aberrant vessel, but this was not surgically corrected. $\mathrm{He}$ developed active pulmonary tuberculosis and is presently on antituberculous therapy.

FIG. 2. Phenotypic features of the cases partially trisomic for chromosome ?18q.

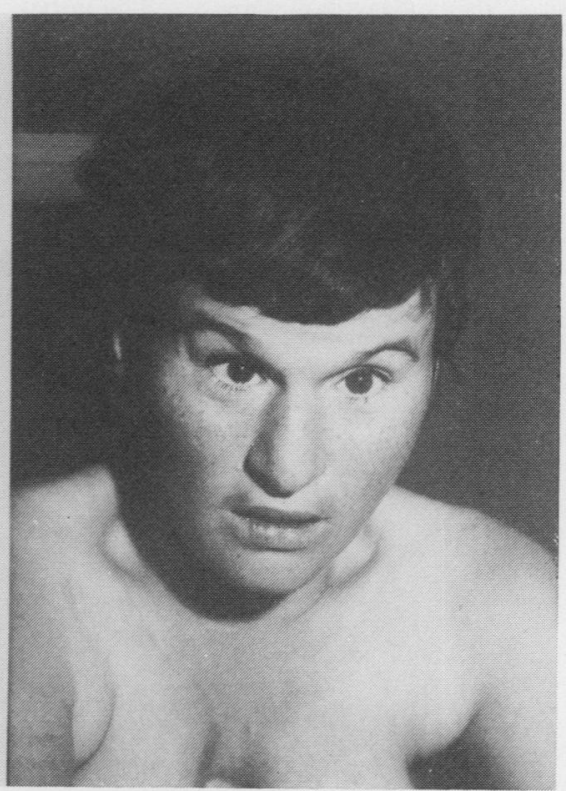

(d)

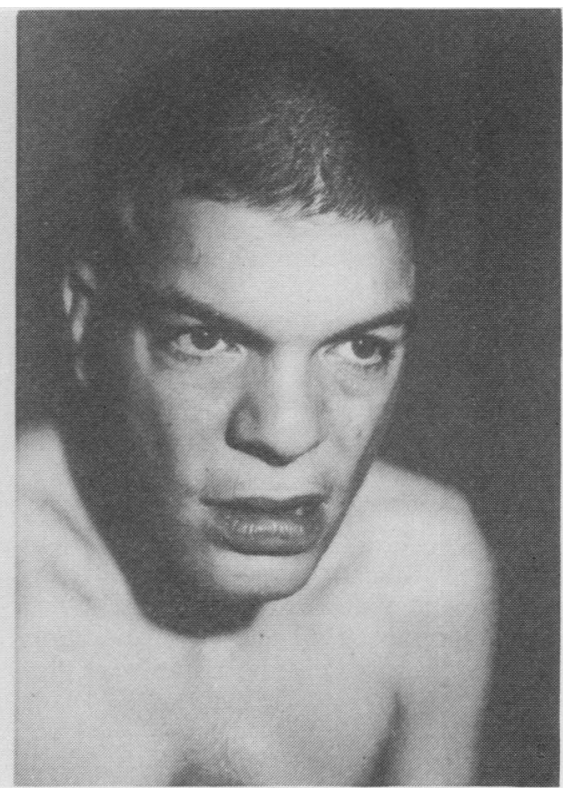

(b) 
Examination revealed a thin male; height $170 \mathrm{~cm}$., weight $56 \mathrm{~kg}$., head circumference $54 \mathrm{~cm}$. He had brachycephaly and prominent orbital ridges, a broad based nose, with a prominent nasal bridge, and bilateral double-creased ear lobes. He had a hypoplastic deformed sternum and kyphoscoliosis of thoraco-lumbar spine. Examination of his extremities showed bilateral simian creases, clinodactyly of index and fifth fingers, and arachnodactyly (Fig. 2c). All secondary sex characteristics were present.

Case II.5 (date of birth 19 April 1940) (Fig. 2d). This 28-year-old woman is the aunt of the proband. She was the product of a full-term pregnancy born at home. The developmental milestones were delayed. At the age of 14 years she was admitted to Ladd School for permanent care. At the chronological age of 19 years, her IQ was less than 30 on the WISC. Her past medical history was negative.

Examination revealed a short, thin apprehensive female; height $146 \mathrm{~cm}$., weight $43.5 \mathrm{~kg}$., head circumference $52 \mathrm{~cm}$. Positive findings include mongoloid slant of eyes, left esotropia, high arched palate, hypoplastic deformed sternum, low hairline, short neck, very protuberant soft abdomen, camptodactyly of the right fourth and fifth fingers, arachnodactyly, and mildly increased muscle tone with a slow 'robot' gait. She had no speech but could comprehend and perform simple commands. All secondary sex characteristics were present.

Case I.1 (date of birth 8 August 1909). This patient is a 60-year-old woman, the maternal grandmother of the proband. She is of dull normal to borderline retarded intellect. She is Gravida 9, Para 8. The initial pregnancy resulted in a miscarriage. The last four case histories were of her four living children; the other four children are deceased and were not examined. However, it is reported that one son was deaf and had a cleft palate; he died at age 18 years of pneumonia. One son died at age 20 months with 'faulty assimilation of food'. One daughter died at age 20 months with septicaemia. One daughter died at age 1 month with spina bifida. All deceased children were reported to be mentally retarded.

\section{Results}

Cytogenetics. Cytogenetic studies were performed on all living members of this pedigree. Standard techniques for blood and tissue culture were used (Moorhead et al., 1960). The results are depicted in the family pedigree (Fig. 3) and summarized on Table I.

Two members (I. 1, II. 9) of the pedigree (Fig. 4) showed a chromosome similar to the $\mathrm{G}$ group which was interpreted as an ?18 with a deletion of approximately one-half of the long arms; there was a marker chromosome in the B group with long long arms. By chromatid measurements, it matched best with the chromosome having the largest arm ratio but smallest overall length and was therefore thought to be a No. 5. This was interpreted to represent a balanced translocation with the karyotype of $46, \mathrm{XX}, \mathrm{t}(? 5 \mathrm{q}+; 18 \mathrm{q}-)$.

Three members (II. 5, II. 7, II. 8) revealed the presence of the marker No. 5 chromosome with a normal appearing $\mathrm{E}$ group, resulting in a partial trisomic state for the long arms of ?18 (Fig. 5).

I
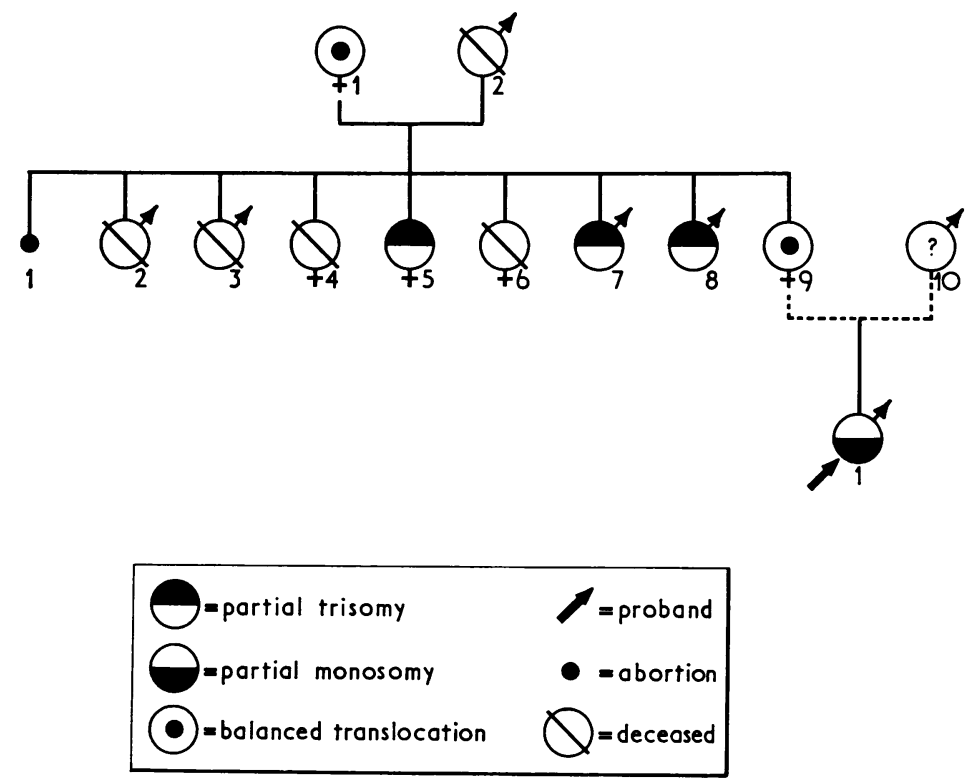

Fig. 3. Family pedigree. 
TABLE I

SUMMARY OF CHROMOSOMAL FINDINGS

\begin{tabular}{|c|c|c|c|c|c|c|c|c|c|c|}
\hline Case & Tissue & $\begin{array}{c}\text { Total } \\
\text { Cells } \\
\text { Counted }\end{array}$ & 43 & 44 & 45 & 46 & 47 & 48 & Karyotype & $\%$ \\
\hline $\begin{array}{l}\text { I.1 } \\
\text { II.9 } \\
\text { II.8 } \\
\text { II.7 } \\
\text { II.5 } \\
\text { III.1 }\end{array}$ & $\begin{array}{l}\text { Peripheral blood (PB) } \\
\text { PB } \\
\text { Skin } \\
\text { PB } \\
\text { PB } \\
\text { PB } \\
\text { PB } \\
\text { Skin }\end{array}$ & $\begin{array}{l}30 \\
30 \\
15 \\
30 \\
30 \\
40 \\
30 \\
35\end{array}$ & $\begin{array}{l}\frac{7}{2} \\
\bar{z} \\
\frac{7}{1}\end{array}$ & $\frac{\frac{2}{1}}{\frac{1}{1}}$ & $\begin{array}{l}4 \\
2 \\
3 \\
2 \\
4 \\
4\end{array}$ & $\begin{array}{r}24 \\
28 \\
9 \\
30 \\
27 \\
36 \\
29 \\
29\end{array}$ & $\begin{array}{l}\bar{z} \\
\bar{z} \\
\bar{z}\end{array}$ & $\begin{array}{l}= \\
\bar{z} \\
=\end{array}$ & 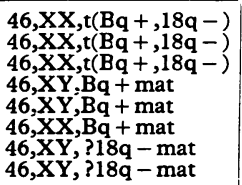 & $\begin{array}{r}100 \\
100 \\
100 \\
100 \\
97 \\
100 \\
100 \\
100\end{array}$ \\
\hline
\end{tabular}

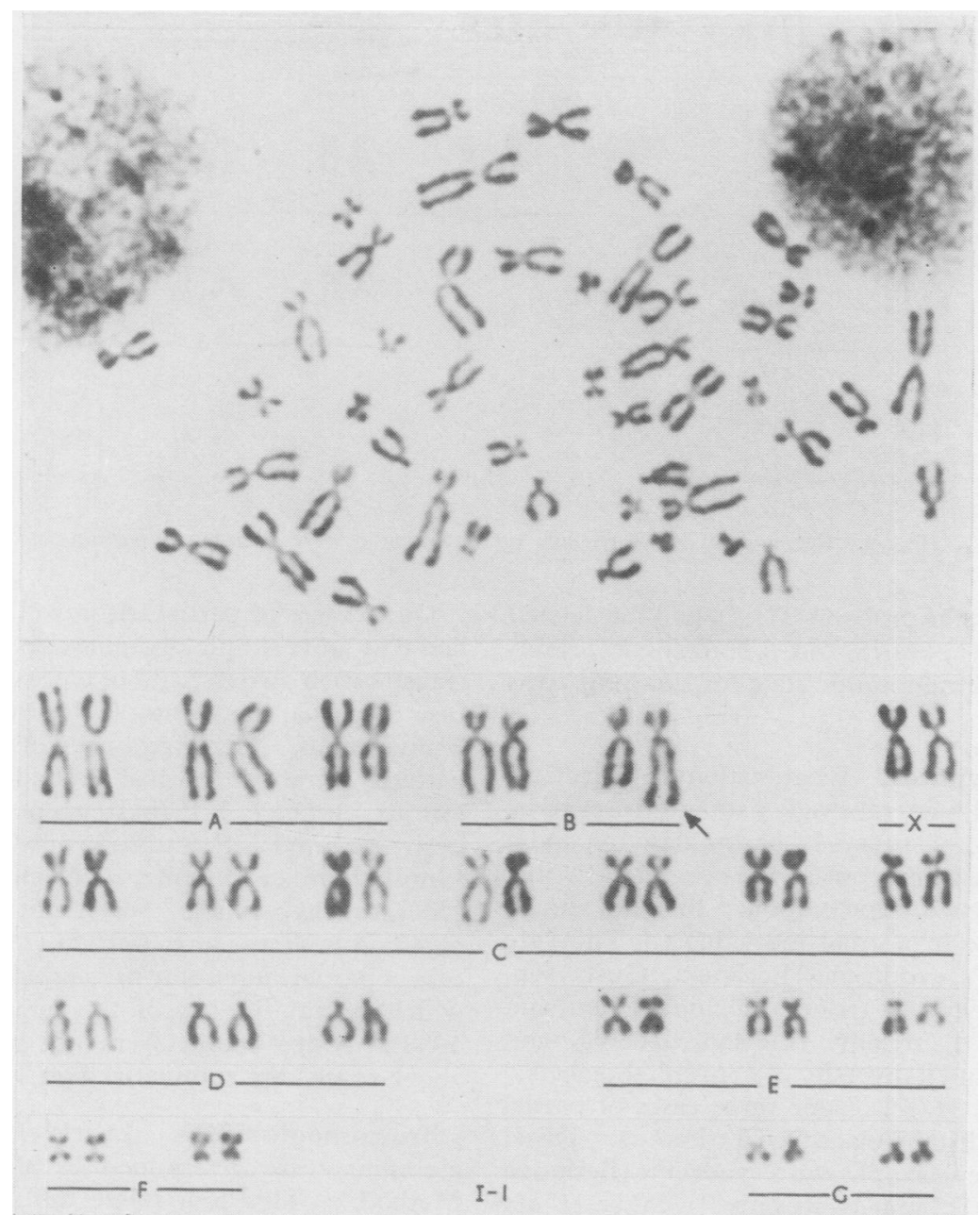

Fig. 4. Karyotype of balanced translocation carrier, showing deletion of half the long arms of a ?18 chromosome and a marker chromosome in'the B group with long long arms. 


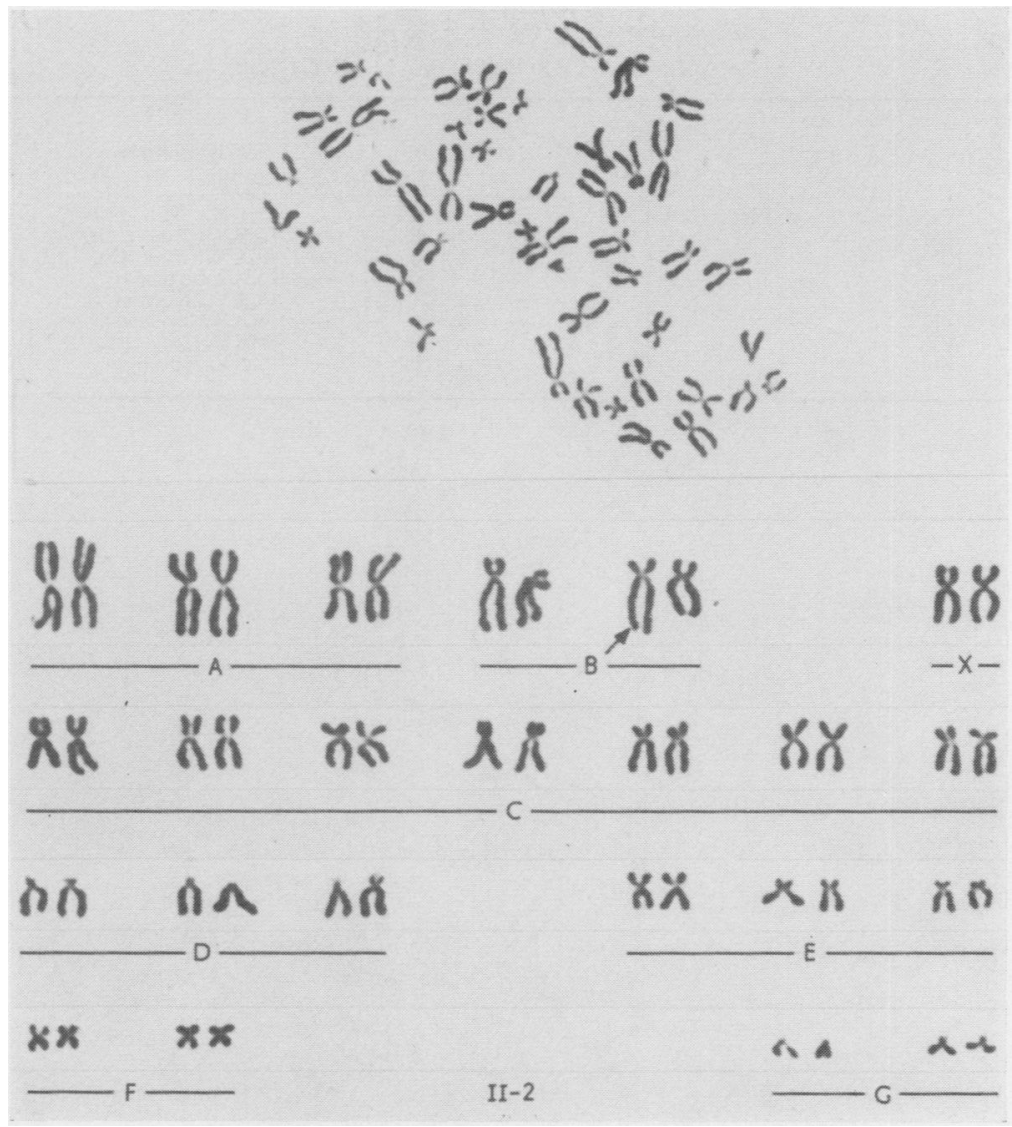

Fig. 5. Karyotype of partial trisomic state, showing a marker B group chromosome.

One member, the proband (III.1), had the deleted ?18 with normal appearing No. 5 homologues, resulting in a partial monosomic state for the long arms of ?18 (Fig. 6).

Dermatoglyphics. Examination of dermatoglyphs revealed bilateral single palmar creases to be present in 2 out of 3 cases of partial trisomy, and a unilateral single palmar crease was present in 1 out of 2 cases of balanced translocation. Bilateral simian creases are rare in normal individuals. They are seen in Down's syndrome (Beckman, Gustavson, and Norring, 1965), D trisomy (Uchida, Patau, and Smith, 1962), E trisomy (Gibson, Uchida, and Lewis, 1963), and a diversity of congenital defects.

Two (II. 5, II. 7) of our three cases of partial trisomy had a distally placed axial triradius. Distal axial triradii are seen in Down's syndrome (Beckman et al., 1965), D and E trisomy (Uchida et al., 1962), Turner's syndrome (Holt and Lindsten, 1964), and congenital heart disease (Sánchez Cascos, 1964).
Our 3 cases of partial trisomy (II. 5, II. 7, II. 8) had 6 or more simple digital arches. The balanced translocation carriers had 7 or more ulnar loops. The case of partial monosomy (III.I) had 3 whorls'and 7 ulnar loops. High frequency of 7 or more of one pattern is rare in normal individuals (Miller and Giroux, 1966). A high frequency of whorls has been reported in Smith-Lemli-Opitz syndrome (Smith, Lemli, and Opitz, 1964) and Eq - syndrome (de Grouchy, 1965). Seven or more arches are common in E trisomy (Gibson et al., 1963). The case of partial monosomy has a proximal hallucal arch which occurs in $1 \%$ of the population (Walker, 1958). Ridge counts were not performed. The above results are summarized on Table II.

Immunoglobulins. Levels of serum immunoglobulins were determined by the Hyland Plate Method.* This is a single diffusion micro-technique in agar (Lou and Shanbrom. 1967). Hyland's 


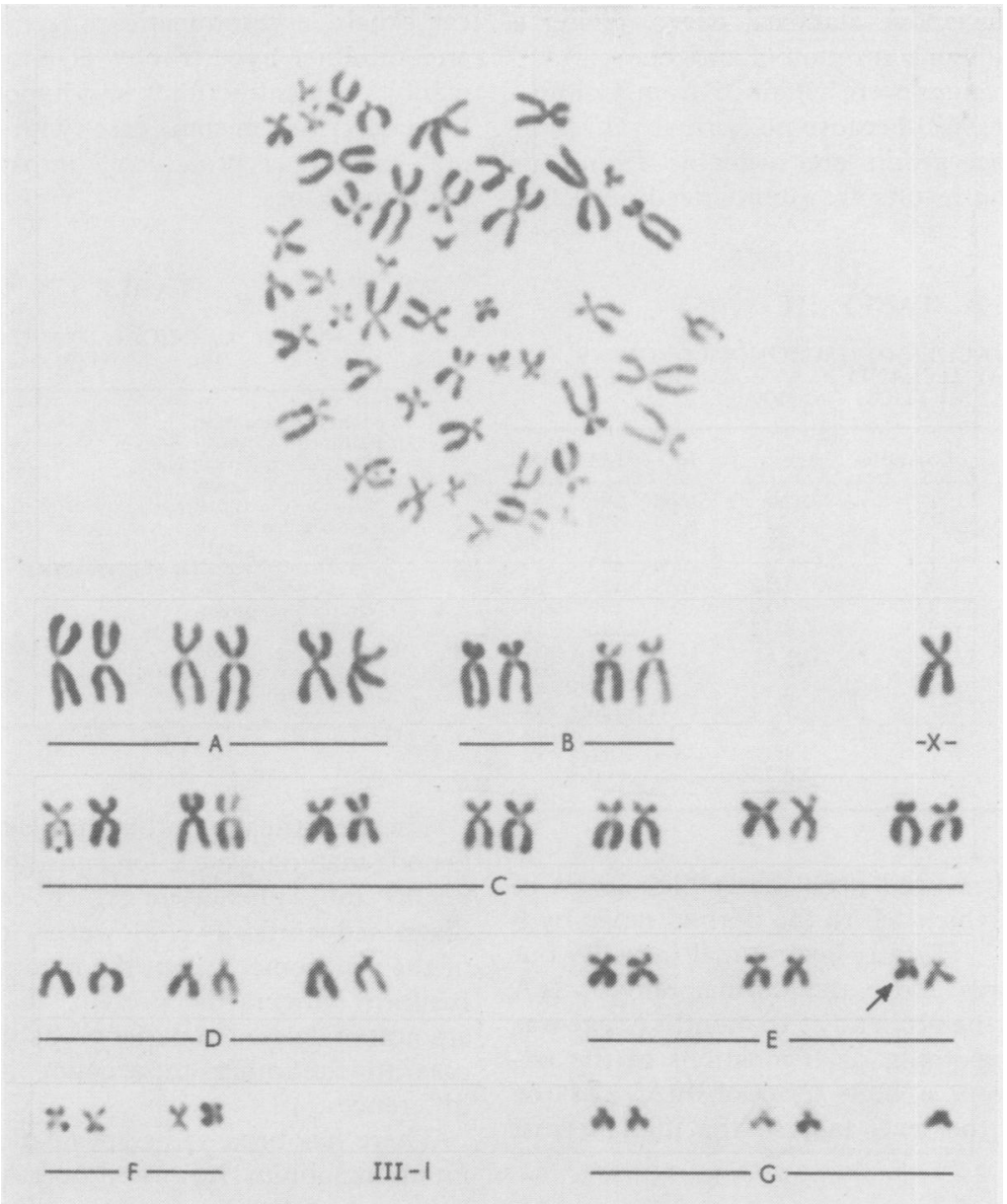

FIG. 6. Karyotype of partial monosomic state, showing partial deletion of the long arms of a ?18 chromosome.

TABLE II

SUMMARY OF DERMATOGLYPHIC PATTERNS

\begin{tabular}{|c|c|c|c|c|c|}
\hline \multirow[t]{2}{*}{ Case } & \multicolumn{2}{|c|}{$\begin{array}{c}\text { Single Palmar } \\
\text { Crease }\end{array}$} & \multicolumn{2}{|c|}{$\begin{array}{l}\text { Triradial } \\
\text { Position }\end{array}$} & \multirow[t]{2}{*}{ Digital Pattern } \\
\hline & Right & Left & Right & Left & \\
\hline I.1 & O & $\mathbf{O}$ & $<20 \%$ & $<20 \%$ & \multirow{5}{*}{$\begin{array}{l}1 \text { radial loop (index) } \\
7 \text { ulnar loops } \\
2 \text { whorls } \\
1 \text { whorl } \\
9 \text { ulnar loops } \\
10 \text { simple arches } \\
1 \text { ulnar loop } \\
9 \text { simple arches } \\
3 \text { ulnar loops } \\
1 \text { whorl } \\
6 \text { simple arches } \\
3 \text { whorls } \\
7 \text { ulnar loops }\end{array}$} \\
\hline II.9 & + & $\mathbf{O}$ & $<20 \%$ & $<20 \%$ & \\
\hline $\begin{array}{l}\text { II. } \\
\text { II. } 7\end{array}$ & + & + & $\begin{array}{r}<20 \% \\
55 \%\end{array}$ & $\begin{array}{r}<20 \% \\
32 \%\end{array}$ & \\
\hline II.5 & O & $\mathbf{O}$ & $42 \%$ & $48 \%$ & \\
\hline III.1 & O & O & $<20 \%$ & $<20 \%$ & \\
\hline
\end{tabular}

immunodiffusion plates consisting of specific antibody-containing agar gel with 6 wells per plate were used in the quantitation of IgG, IgA, and IgM. When antigen is placed in the well, it diffuses into the antibody-containing agar gel and forms a precipitin ring, the diameter of which is directly related to the initial concentration of the antigen. The procedure involves filling the wells with undiluted serum. This method may not be as accurate as serial dilution techniques. The IgG is incubated for 4 hours at $37^{\circ} \mathrm{C}$. The IgA and IgM remain at room temperature for 16 hours. The results are compared to reference standards supplied by Hyland Laboratories from which a daily standard curve is constructed. The diameter of precipitin ring is 
compared to the above standard curve, giving a direct estimate of concentration of antigen.

The normal values were obtained from CollinsWilliams et al. (1967) because no normal values for the pediatric age-group are available from our laboratory. The results are summarized on Table III.

TABLE III

MEAN VALUES OF IMMUNOGLOBULINS DETERMINED BY HYLAND PLATE 'IMMUNOPLATE' METHOD (mg./100 ml.)

\begin{tabular}{|c|c|c|c|c|c|c|}
\hline Case & Source & No. of Samples & Age (yr.) & IgG & IgA & $\operatorname{Ig} M$ \\
\hline $\begin{array}{l}\text { I.1 } \\
\text { II. } 8 \\
\text { II.7 } \\
\text { II. } 5 \\
\text { III. } 1\end{array}$ & $\begin{array}{l}\text { Stool } \\
\text { Saliva } \\
\text { Tears }\end{array}$ & $\begin{array}{l}1 \\
1 \\
1 \\
1 \\
6 \\
3 \\
3 \\
1 \\
2 \\
3 \\
2 \\
2 \\
2 \\
1\end{array}$ & $\begin{array}{c}60 \\
22 \\
24 \\
28 \\
4 / 12 \\
7 / 12 \\
9 / 12 \\
1 \\
18 / 12 \\
4 / 12 \\
7 / 12 \\
1 \\
4 / 12 \\
18 / 12\end{array}$ & $\begin{array}{r}2000 \\
1030 \\
1125 \\
1030 \\
289 \\
320 \\
743 \\
1150 \\
985 \\
9 \\
0 \\
15 \\
9\end{array}$ & $\begin{array}{r}290 \\
370 \\
450 \\
433 \\
171 \\
139 \\
46 \\
36 \\
85 \\
235 \\
120 \\
0 \\
11 \\
0\end{array}$ & $\begin{array}{r}290 \\
110 \\
109 \\
110 \\
57 \\
76 \\
31 \\
61 \\
85 \\
47 \\
153 \\
105 \\
35\end{array}$ \\
\hline
\end{tabular}

The proband showed persistently high levels of IgA in infancy which fell to the normal range by 9 months of age. IgG was low normal initially, but by 9 months was above the normal range. IgA level on tears in the proband at 18 months of age was zero. Immunoglobulin determinations of the trisomic state shows a high level of IgA. In the balanced state, the level falls in the high normal range.

\section{Discussion}

The proband, who is monosomic for approximately one-half of the long arms of chromosome 18, has many features in common with similar cases reported previously (Day et al., 1967; de Grouchy et al., 1964a, b; de Grouchy, 1965; Destiné et al., 1967; Feingold and Schwartz, 1968; Feingold et al., 1969; Insley, 1967; Kushnick and Matsushita, 1968; Lafourcade and Lejeune, 1967, 1968; Law and Masterson, 1966; Lindsjö and Hall, 1967; Lejeune et al., 1966b; Reinwein, Gorman, and Wolf, 1967; Rudd, May, and LaMarche, 1969; Schmid and Vischer, 1967; Stewart et al., 1968; Valdmanis et al., 1967; Wolf et al., 1967; Wertelecki, Schindler, and Gerald, 1966). Table IV summarizes the frequency of the principal clinical features of the $18 q-$ syndrome as reported in the literature. The proband in our family exhibits mental retardation, failure to thrive, microcephaly, midface retraction, carp mouth, fusiform fingers, stenotic ear canals, asymptomatic congenital heart disease, and minimal hypertrophy of antitragus. $\mathrm{He}$ also exhibits epicanthic folds and hypotonia which have been described in some cases with $18 \mathrm{q}-$. He does not exhibit cryptorchism, impaired hearing, or malformed toes.

\section{TABLE IV}

\begin{tabular}{|c|c|}
\hline $\begin{array}{c}\text { PRINCIPAL CLINICAL SYMPTOMS } \\
\text { ?18q - SYNDROME }\end{array}$ & OF \\
\hline $\begin{array}{l}\text { Mental retardation } \\
\text { Failure to thrive } \\
\text { Moderate microcephaly } \\
\text { Midface retraction } \\
\text { Hypertrophic antitragus and/or antihelix } \\
\text { Carp mouth } \\
\text { Fusiform fingers } \\
\text { Optic atrophy/ocular abnormalities } \\
\text { Excess whorls (\%) } \\
\text { Dimpled acromian } \\
\text { Hearing loss } \\
\text { Stenotic ear canals } \\
\text { Congenital heart disease } \\
\text { Micrognathia }\end{array}$ & $\begin{array}{l}26 / 27 \\
21 / 24 \\
20 / 23 \\
18 / 21 \\
23 / 25 \\
13 / 16 \\
15 / 15 \\
16 / 26 \\
17 / 20 \\
9 / 12 \\
2 / 4 \\
4 / 4 \\
5 / 6 \\
2 / 3\end{array}$ \\
\hline
\end{tabular}

There is little doubt that the deletion of part of the genetic material on the long arms of chromosome 18 results in a phenotype which can be frequently diagnosed clinically. However, no single feature of the syndrome, except the mental retardation and fusiform fingers is present in all cases. The amount of deleted material probably varies from one case to the other to account for these clinical differences.

There has been some speculation lately that the immunoglobulin IgA may be associated with the long arm of 18 chromosome. Finley et al. (1968) reported absence of $\operatorname{IgA}$ in serum and saliva associated with a ring 18 chromosome. Subsequently, Richards and Hobbs (1968) reported a case of ring 18 chromosome associated with normal serum IgA and low normal salivary IgA. They postulated a smaller deletion of $18 q$ - than in the patient previously described. Stewart et al. (1968) described the first case of $18 \mathrm{q}$ - associated with absent serum and salivary IgA, and a case of ring 18 mosaicism with normal IgA. Feingold and Schwartz (1968) reported normal levels of immunoglobulins in several other types of chromosomal deletion syndromes. Later, Feingold et al. (1969) published absence of IgA in two further cases: $18 \mathrm{q}$ - and ring 18 chromosome. Hecht (1969) reported a case of low IgA serum levels in trisomy 18. We issued a preliminary report (Rudd et al., 1969) of the proband in this family who showed persistently raised levels of serum IgA in infancy. Serum IgA levels show a great variation in the first year of life 
and these high levels may not represent a true increase. In addition, the presence of an unidentified malabsorption syndrome in this infant during this period complicates the picture. However, the inconsistency in IgA levels seen in reported cases of the deleted state as well as the trisomic state for chromosome 18 would be contrary to the genedosage hypothesis previously suggested. Chromosome 18 may well be associated with the IgA immunoglobulins; however, it does not appear to be consistently affected by the excess or absence of a portion of the long arm of No. 18.

Since Edwards' first report (Edwards et al., 1960), several cases of partial 18 trisomy have been reported due to translocation of part of that chromosome to another autosome: in some cases to a B group (Alberty et al., 1968; France and Butler, 1969; Freiman and Wilton, 1967; Gagnon et al., 1963; Valdmanis et al., 1967); in some cases to a D group (Brodie and Dallaire, 1962; Hecht et al., 1963); and in one case to an E group (Rohde, Lee, and Sapin, 1963). All these cases demonstrated many of the clinical features of trisomy 18 syndrome. In our family the three cases of partial trisomy 18 due to translocation also demonstrate a few of the clinical features of trisomy 18. A comparative summary appears on Table V. Clinical features

\section{TABLE V}

COMPARATIVE SUMMARY OF CLINICAL FINDINGS IN PARTIAL TRISOMY 18 SYNDROME WITH FULL TRISOMY 18 SYNDROME

\begin{tabular}{l|c}
\hline \multicolumn{1}{c|}{ Trisomy 18 } & Partial Trisomy 18 \\
\hline \multicolumn{1}{c|}{$\begin{array}{c}\text { Features in Common } \\
\text { Failure to thrive }\end{array}$} & + \\
Mental deficiency & + \\
Narrow high palatal arch & + \\
Short sternum & + \\
Cryptorchism & + \\
6 or more simple digital arches & + \\
$\quad$ Features Notably Absent & \\
Prominent occiput & - \\
Micrognathia & - \\
Congenital heart disease & - \\
Low set malformed ears & - \\
Prominent calcaneous & - \\
Sublethality & - \\
\hline
\end{tabular}

appearing in our cases of partial trisomy 18 which are in common with the complete trisomy 18 are: failure to thrive; mental deficiency; narrow, high palatal arch; short sternum; cryptorchism; and 6 or more simple digital arches. Several features frequently found in trisomy 18 are notably absent in our cases, namely prominent occiput, micrognathia, congenital heart disease, low set malformed ears, and prominent calcaneous as well as sublethality. Some features are present but modified: the flexion deformity of the index and fifth digit commonly seen in the full trisomy appears as mild clinodactyly of the same fingers in the two males; hypertonicity is present but mild; simian creases are present in both males but absent in the female.

The differences in phenotype in the two groups may be on the basis of partial trisomy as opposed to complete trisomy. Generally, in comparing complete autosomal trisomies to partial trisomies, there appears to be a direct and positive correlation between the degree of trisomy and the severity of phenotypic expression.

The consequences of translocations are profound. They lead not only to a change in gene linkage in the translocated sections but also to easily incurred meiotic abnormalities. Therefore, in addition to the four gamete possibilities in a balanced translocation carrier illustrated by the living members of this family pedigree, there are innumerable additional possibilities which could be incurred by meiotic errors. The latter mechanism may account for the lethal state in the initial pregnancy, the child with spina bifida, or the child with failure to thrive who died of thigh abcesses. The boy with deafness and cleft palate, and the child with 'faulty assimilation of food' may also have been partially monosomic for ? 18 long arm; however, this can only be speculative.

\section{Summary}

A family of three generations is presented with a translocation abnormality of about one-half of the long arm of a submedian $\mathrm{E}$ group chromosome ( ?18q) to the long arm of a $B$ group chromosome. The clinical features of the $18 \mathrm{q}$ - were compared with those previously reported. The three cases of partial trisomy were compared with the clinical picture of complete trisomy 18 . IgA immunoglobulin variability associated with 18 chromosome was discussed.

The authors wish to thank Dr. Peter Mathieu and Dr. Nedo Nora for permission to study their patients. The technological assistance of Mr. Daniel Dunwoodie and Miss Kathy Hunter is also gratefully acknowledged. This study was supported in part by a grant from the National Foundation.

\section{REFERENCES}

Alberty, J., Théodoridès, M., Guillard, J. M., Sandler, B., and Verger, P. (1968). Une paire de chromosomes asymétriques dans le groupe B (4-5) chez une enfant dont le phénotype présente les caractères d'une trisomie du groupe $\mathrm{E}$ (Edwards). Bordeaux Médical, 1, 2039-2050.

Beckman, L., Gustavson, K. H., and Norring, A. (1965). Dermal configurations in the diagnosis of the Down syndrome: An attempt at a simplified scoring method. Acta Genetica et Statistica Medica, 15, 3-12. 
Brodie, H. R. and Dallaire, L. (1962). The E Syndrome (trisomy 17-18) resulting from a maternal chromosomal translocation. Canadian Medical Association fournal, 87, 559-561.

Collins-Williams, C., Toft, B., Generoso, L., and Moscarello, M. (1967). Quantitative immunoglobulin levels (IgG, IgA and IgM) in children, determined by the Hyland Immunoplate technique. Canadian Medical Association fournal, 96, 1510-1513.

Day, E. J., Marshall, R., Macdonald, P. A. C., and Davidson, W. M. (1967). Eq-Deleted chromosome 18 with paternal mosaicism. Lancet, 2, 1307.

de Grouchy, J. (1965). Chromosome 18: A topologic approach. fournal of Pediatrics, 66, 414-431.

-, Lévêque, B., Debauchez, C., Salmon, Ch., Lamy, Maurice and Marie, Julien (1964a). Chromosome 17-18 en anneau et malformations congénitales chez une fille. Annales de Génétique, 7, 17-23.

-, Royer, P., Salmon, Ch., and Lamy, M. (1964b). Délétion partielle des bras longs du chromosome 18. Pathologie et Biologie, $12,579-582$.

Destiné, M. L., Punnett, H. H., Thovichit, S., DiGeorge, A. M., and Weiss, L. (1967). La délétion partielle du bras long du chromosome 18. (Syndrome 18q-). Rapport de deux cas. Annales de Génétique, 10, 65-69.

Edwards, J. H., Harnden, D. G., Cameron, A. H., Crosse, V. M., and Wolf, O. H. (1960). A new trisomic syndrome. Lancet, 1, 787-790.

Feingold, M. and Schwartz, R. S. (1968). IgA and partial deletions of chromosome $18 . \quad$ Lancet, $2,1086$.

—, Schwartz, R. S., Atkins, L., Anderson, R., Bartsocas, C. S. Page, D. L., and Littlefield, J. W. (1969). IgA deficiency associated with partial deletion of chromosome 18. American fournal of Diseases of Children, 117, 129-136.

Finley, S. C., Finley, W. H., Noto, T. A., Uchida, I. A., and Roddam, R. F. (1968). IgA absence associated with a ring-18 chromosome. Lancet, 1, 1095-1096.

France, N. E. and Butler, L. J. (1969). Trisomy 18 associated with a familial translocation $(\mathrm{Bq}-, 18 \mathrm{q}+)$. Annales de Génétique, 12, 4650.

Freiman, I. and Wilton, E. (1967). Trisomy 16-18 in the Bantu. South African Medical fournal, 41, 558-561.

Gagnon, J., Archambault, L., Laberge, E., and Katyk-Longtin, N. (1963). Trisomie partielle 18 par insertion ou translocation $4 / 18$. Union Médicale du Canada, 92, 311-319.

Gibson, D. A., Uchida, I. A., and Lewis, A. J. (1963). A review of the 18 trisomy syndrome. Medical and Biological Illustration, 13, 80-88.

Hecht, F. (1969). IgA and partial deletions of chromosome 18. Lancet, 1, 100-101.

- Bryant, J., Arakaki, D., Kaplan, E., and Gentile, G. (1963). Trisomy-18 syndrome due to de-novo translocation. Lancet, 1 , 114.

Holt, S. B. and Lindsten, J. (1964). Dermatoglyphic anomalies in Turner's syndrome. Annals of Human Genetics, 28, 87-100.

Insley, J. (1967). Syndrome associated with a deficiency of part of the long arm of chromosome no. 18. Archives of Disease in Childhood, 42, 140-146.

Kushnick, T. and Matsushita, G. (1968). Partial deletion of long arms of chromosome 18 . Pediatrics, 42, 194-197.

Lafourcade, J. and Lejeune, J. (1967). Le phenotype (18q-). fournées Parisiennes de Pediatrie, 14-15, 303-311. and - (1968). La déficience du bras long d'un chromo- $(\mathbb{D}$ some 18 (18q-). Union Médicale du Canada, 97, 936-940.

Law, E. M. and Masterson, J. G. (1966). Partial deletion of chro- $\stackrel{\mathbb{P}}{?}$ mosome 18. Lancet, 2, 1137.

Lejeune, J., Berger, R., Lafourcade, J. and Réthoré, M. O. (1966a). La délétion partielle du bras long du chromosome 18: individualisation d'un nouvel état morbide. Annales de Génétique, 9, 32-38.

-, Réthoré, M. O., Berger, R., Baheux, G., and Chabrun, J. (1966b). Sur un cas de chromosome 18 en anneau. Annales de Génétique, 9, 173-175.

$\longrightarrow$, - , Réthoré, M. O., Lafourcade, J., Dutrillaux, B., Canlorbe, $\stackrel{\mathbb{Q}}{\varrho}$ P., and Labrune, B. (1967). Deux cas de syndrome $18 \mathrm{q}-$ en 24.

Lindsjö, A. and Hall, B. (1967). Partial monosomy of the long arm of an E chromosome-a new syndrome. Hereditas, Genetiskt Arkiv, 57, 205-208.

Lou, K. and Shanbrom, E. (1967). Immunodiffusion techniques in clinical medicine. II. radial immunodiffusion. Fournal of the American Medical Association, 200, 323.

Miller, J. R. and Giroux, J. (1966). Dermatoglyphics in pediatric $\infty$ practice. Fournal of Pediatrics, 69, 302-312.

Moorhead, P. S., Nowell, P. C., Mellman, W. J., Battips, D. M., and Hungerford, D. A. (1960). Chromosome preparations of leukocytes cultured from human peripheral blood. Experimental Cell $ᄋ$ Research, 20, 613-616.

Reinwein, H., Gorman, L. Z., and Wolf, U. (1967). Defizienz am langen Arm eines Chromosoms Nr. 18 (46,XX,18q-). Zeitschrift für Kinderheilkunde, 101, 152-164.

Richards, B. W. and Hobbs, J. R. (1968). IgA and ring-18 chromosome. Lancet, 1, 1426-1427.

Rohde, R. A., Lee, A., and Sapin, S. (1963). A new trisomy-translocation chromosome (long-arm E/E.) Lancet, 2, 1309-1310.

Rudd, N. L., May, J. B., and LaMarche, P. H. (1969). IgA and partial deletions of chromosome 18. Lancet, 1, 100.

Sánchez Cascos, A. (1964). Finger print patterns in congenital heart disease. British Heart fournal, 26, 524-527.

Schmid, W. and Vischer, D. (1967). Zwei Fälle von partieller Deletion des Chromosoms 18. Fahresversammlung der Schweizerischen Gesellschaft für Pädiatrie, 6, 16-18.

Smith, D. W., Lemli, L., and Opitz, J. M. (1964). A newly recognized syndrome of multiple congenital anomalies. fournal of Pediatrics, 64, 210-217.

Stewart, J., Go, S., Ellis, E., and Robinson, A. (1968). IgA and partial deletions of chromosome 18 . Lancet, $2,779$.

Uchida, I. A., Patau, K., and Smith, D. W. (1962). Dermal patterns of 18 and D1 trisomics. American fournal of Human Genetics, 14, 345-352.

Valdmanis, A., Pearson, G., Siegel, A. E., Hoeksema, R. H., and Mann, J. D. (1967). A pedigree of $4 / 18$ translocation chromosomes with type and countertype partial trisomy and partial monosomy for chromosome 18. Annales de Génétique, 10, 159-166.

Walker, N. F. (1958). The use of dermal configuration in the diagnosis of mongolism. Pediatric Clinics of North America, 531-543.

Wertelecki, W., Schindler, A. M., and Gerald, P. S. (1966). Partial deletion of chromosome 18. Lancet, 2, 641 .

Wolf, U., Reinwein, H., Gorman, L. Z., and Künzer, W. (1967). Deletion on long arm of a chromosome $18(46, \mathrm{XX}, 18 \mathrm{q}-)$. Humangenetik, 5, 70-71. 